Review article / Обзорная статья

УДК 547.569.1+547.569.8+547.314.2

DOI: https://doi.org/10.21285/2227-2925-2019-9-4-576-589

\title{
Chalcogenisation of unsaturated organohalogen compounds by elemental chalcogens and their metal derivatives
}

\author{
(c) Igor B. Rozentsveig ${ }^{\star \star \star \star}$, Valentina S. Nikonova*, Nikolai A. Korchevin ${ }^{\star \star \star \star \star}$ \\ ${ }^{*}$ A.E. Favorsky Irkutsk Institute of Chemistry SB RAS, Irkutsk, Russian Federation \\ ** Irkutsk State University, Irkutsk, Russian Federation \\ *** Angarsk State Technical University, Angarsk, Russian Federation
}

\begin{abstract}
The presented review addresses the prospects for application of organochalcogen compounds in various fields of technology, medicine, agriculture and organic synthesis. The unsaturated chalcogenisation products appear to be of much greater interest compared to their saturated analogues, especially in organic synthesis. This study observes halogen derivatives of ethene, propene, propyne and butene subjected to chalcogenisation as unsaturated substrates. The indicated reagents are related either to large-tonnage products of industrial organochlorine synthesis or waste products of organochlorine production with their disposal presenting an important environmental task. According to analysed publications, chalcogenisation processes are based on the application of elemental chalcogens (sulphur, selenium, and tellurium) or their available metal derivatives $\left(\mathrm{Na}_{2} \mathrm{~S}\right.$, etc.). In the reactions of chalcogens with unsaturated halogen derivatives, the elements both in an accessible form and in a free state are subjected to reductive activation resulting in the formation of anionic nucleophilic reagents. Complex metal hydrides, chalcogenide anions and rongalite are exampled for application in terms of reducing agents. The review emphasises the prospects of basic reduction systems based on hydrazine hydrate in activation processes. Special aspects in the introduction of caustic alkalis and an monoethanolamine organic amine as bases in these systems are described. For the considered chalcogenisation processes, conditions are specified providing the most optimal yield of certain products. In some particular cases, the stereochemistry of the obtained compounds is presented considering the formation conditions for the stereoisomers of a certain configuration. For a number of the obtained compounds, the prospects of practical application are provided. In general, the current review is intended for specialists working in the field of organic synthesis and application of organochalcogen compounds.
\end{abstract}

Keywords: organochalcogen compounds, chalcogenisation, chalcogens, unsaturated organohalogen compounds, hydrazine hydrate-base systems

Information about the article: Received August 14, 2019; accepted for publication November 25, 2019; available online December 30, 2019.

For citation: Rozentsveig IB, Nikonova VS, Korchevin NA. Chalcogenisation of unsaturated organohalogen compounds by elemental chalcogens and their metal derivatives. Izvestiya Vuzov. Prikladnaya Khimiya i Biotekhnologiya $=$ Proceedings of Universities. Applied Chemistry and Biotechnology. 2019;9(4):576-589. (In English) https://doi.org/10.21285/2227-2925-2019-9-4-576-589

\section{Халькогенирование ненасыщенных галогенорганических соединений элементными халькогенами и их металлическими производными}

\author{
И.Б. Розенцвейг ${ }^{* \star * *}$, В.С. Никонова*, Н.А. Корчевин ${ }^{* \star \star \star *}$ \\ * Иркутский институт химии им. А.Е. Фаворского СО РАН, г. Иркутск, Российская Федерация \\ ** Иркутский государственный университет, г. Иркутск, Российская Федерация \\ *** Ангарский государственный технический университет, г. Ангарск, Российская Федерация
}

Резюме: В представленном обзоре рассмотрены вопросы, касающиеся перспектив использования халькогенорганических соединений в медицине, сельском хозяйстве, в различных областях техники и в органическом синтезе. Показано, что ненасыщенные продукты халькогенирования представляют 
гораздо больший интерес по сравнению с их насыщенными аналогами, особенно при использовании в органическом синтезе. В качестве ненасыщенных субстратов, подвергаемых халькогенированию, представлены галогенпроизводные этена, пропена, пропина и бутена. Указанные реагенты относятся либо к многотоннажным продуктам промышленного хлорорганического синтеза, либо являются отходами хлорорганических производств, утилизация которых является важной экологической задачей. Проанализированные публикации отражают процессы халькогенирования, базирующиеся на использовании элементных халькогенов (серы, селена и теллура) или их доступных металлических производных ( $\mathrm{Na}_{2} \mathrm{~S}$ и др.). Для осуществления реакций халькогенов с ненасыщенными галогенпроизводными элементы в доступной форме в свободном состоянии подвергают восстановительной активации, в результате которой образуются анионные нуклеофильные реагенты. В качестве восстановителей показаны примеры использования комплексных гидридов металлов, халькогениданионов и ронгалита. В обзоре подчеркнуты перспективы применения для целей активации основно-восстановительных систем на базе гидразингидрата. Показаны особенности введения в качестве оснований в эти системы едких щелочей и органического амина - моноэтаноламина. Для рассмотренных процессов халькогенирования указаны условия, обеспечивающие наиболее оптимальные выходы определенных продуктов. В необходимых случаях представлена стереохимия получаемых соединений и рассмотрены условия образования стереоизомеров определенной конфигурации. Для некоторых получаемых соединений показаны перспективы практического применения. Материал обзора будет полезен специалистам в области органического синтеза и практического использования халькогенорганических соединений.

Ключевые слова: халькогенорганические соединения, халькогенирование, халькогены, ненасыщенные галогенорганические соединения, системы гидразингидрат-основание

Информация о статье: Дата поступления 14 августа 2019 г.; дата принятия к печати 25 ноября 2019 е.; дата онлайн-размещения 30 декабря 2019 г.

Для цитирования: Розенцвейг И.Б., Никонова В.С., Корчевин Н.А. Халькогенирование ненасыщенных галогенорганических соединений элементными халькогенами и их металлическими производными // Известия вузов. Прикладная химия и биотехнология. 2019. Т. 9. N 4. С. 576-589. https://doi.org/10. 21285/2227-2925-2019-9-4-576-589

\section{INTRODUCTION}

The scope of organic chalcogen compounds can be seen to be constantly expanding. Although sulphur and its organic derivatives have been applied by humans since ancient times, more recent uses include unique medicines created on their basis, including antibiotics, anticancer drugs, drugs for human immunodeficiency, as well as protector drugs against ionising radiation. The technological application of organosulphur compounds is associated with the development of rubber vulcanisation agents, dyes, photographic materials, complexing agents, flotation reagents and extractants, polymerisation process regulators, as well as with the creation of corrosion protection agents and new types of polymeric materials, in particular for new generation chemical current sources and others directions [1]. The use of selenium and tellurium compounds was clearly indicated only in the second half of the last century and was associated, first of all, with their technical application in obtaining ligands for complex formation, organic semiconductors and electrically conductive polymers [2, 3]. However, in recent decades, numerous data have been obtained on the biological role of selenium and tellurium organic derivatives [4-6]. A detailed study for the structure of organochalcogen compounds (OCC) served as an impetus for the development of many theoretical concepts in organic chemistry [7-9]. An important direction in the application of OCCs involves their use as precursors in contemporary organic synthesis [10-12]. By virtue of these precursors, new nanomaterials, analogues of natural compounds are obtained along with typically unstable, highly reactive compounds. Thus, the synthesis and use in modifying drugs of this class of compounds presents a specific task in modern organic chemistry.

The development and improvement of methods for OCC synthesis is constantly stimulated by the continuous expansion in the scope of their application. The most universal method of introducing a chalcogenyl substituent into the structure of an organic molecule involves the nucleophilic substitution of halogen. Chalcogen-containing anions manifest themselves as nucleophiles in these reactions $\left(Y^{2-}, Y_{n}{ }^{2-}, R Y^{-}\right.$with $Y=S$, Se, Te and $R$ denoting an organic radical). The specified anionic forms are included in some commercial chemicals, mainly sodium sulphide, applied in the form of nanohydrate $\left(\mathrm{Na}_{2} \mathrm{~S} \cdot 9 \mathrm{H}_{2} \mathrm{O}\right)$. The application of the considered chalcogenide reagents is directly related to the possibility of their generation from accessible, storage-stable elemental chalcogens. In order introduce them into a nucleophilic substitution reaction, simple substances are converted into an anionic form by chemical activation carried out due to the reductive splitting of $Y-Y$ bonds in elemental 
chalcogens. Currently, although a wide range of reducing systems is available for application, their use is typically associated with the involvement of explosive reagents (organic derivatives of metals, hydrides and complex hydrides), toxic and combustible solvents, compounds of heavy metals in lower oxidation states and other factors reducing the preparative value of the developed methods. The generation of chalcogen-containing nucleophiles is effectively carried out using the hydrazine hydrate-alkali basic reduction system [13] and can be represented by the following scheme:

$$
\underset{n=1-4}{2 n Y}+\mathrm{N}_{2} \mathrm{H}_{4} \cdot \mathrm{H}_{2} \mathrm{O}+4 \mathrm{KOH} \rightarrow 2 \mathrm{~K}_{2} \mathrm{Y}_{n}+\mathrm{N}_{2}+5 \mathrm{H}_{2} \mathrm{O}
$$

In this reaction, the value of $n$ is determined by the $\mathrm{Y}$ : $\mathrm{KOH}$ ratio.

Here, the resulting chalcogenide and polychalcogenide anions are reacting in the synthesis directly in the hydrazine hydrate solution without being isolated in an individual state. Using this activation method, a large number of saturated OCCs have been synthesised, including chalcogen-containing polymers and heterocyclic systems, some of whose unique properties have been described (see, for example, [14]).

From a practical point of view, OCCs with multiple structural bonds are of particular interest due to their significant expansion of the synthetic potential and practical significance of the studied compounds. In order to synthesise them, reactions of chalcogen-containing nucleophiles with unsaturated organohalogen compounds can be applied. In the substrates under consideration, halogen atoms can be attached to carbon atoms in both the $s p^{3}$ hybridisation state, characterised by nucleophilic reactions to proceed fairly easy, and the $s p^{2}$ hybridisation state. In the latter case, nucleophilic substitution may be hindered [15]. When the conditions change, halogen vinyl fragments in the resulting products enter into further chemical transformations, ensuring cascade reactions allowing valuable OCCs to be obtained.

The present review provides the main research results with the objects of study consisting in organohalogen derivatives of ethylene, propylene, pro- pyne and butylene. In addition, such derivatives are to be highlighted as relating either to large-tonnage organochlorine products or substances generated from organochlorine production wastes.

Halcogenisation of ethylen chlorinated derivatives. Thiylation of vinyl halides or their derivatives, having a halogen atom attached to the $s p^{2}$-hybridised carbon atom, is carried out either using photochemical and thermal assistance $[16,17]$ or by means of aprotic highly polar solvents [17]. In nucleophilic reactions, only di- and polyhalogen derivatives of ethene were studied.

The ethylene dichloro-derivatives 1,1-dichloroethene (vinylidene chloride) (1a) and 1,2-dichloroethene ( $E$ - and $Z$-isomers) (1b) present commercially available monomers and reagents. The unsaturated organochalcogen compounds obtained on their basis open up wide possibilities for the synthesis of polyfunctional $n, \pi$-ligands for complexation with transition metal ions.

The work [18] describes the photochemical reaction of atomic sulphur with 1,2-dichloroethene (1b), resulting in a low yielded dichlorothiirane. However, when the $Z-1 b$ compound and sodium sulphide nonahydrate reacts in acetonitrile with the presence of 15 -crown-5 interphase transfer catalyst ( 0.4 equiv.), a mixture of cyclic unsaturated sulphur-containing compounds - unsaturated thiacrown esters (2a-h) - was obtained at room temperature in $45 \mathrm{~h}$ with a total yield of $40 \%$ [19] (Scheme 1).

Scheme 1

Схема 1

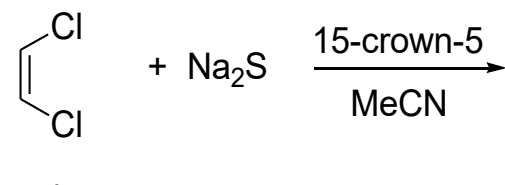

$1 b$

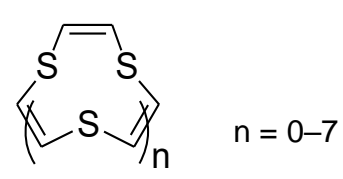

$2 d-h$ $n=0,2 \mathrm{a}(44 \%)^{*} ; n=1,2 \mathrm{~b}(3 \%) ; n=2,2 \mathrm{c}$ (traces); $n=3,2 \mathrm{~d}(4 \%) ; n=4,2 \mathrm{e}(18 \%) ; n=5,2 \mathrm{f}(16 \%)$; $n=6,2 \mathrm{~g}(10 \%) ; n=7,2 \mathrm{~h}(5 \%)$.

* product concentration in the mixture, according to $\mathrm{H}$ NMR data.

X-ray diffraction data were obtained for the synthesised thiacrown esters, presenting all sulphur atoms in the cycle to be directed inward (endodentate ligand), i.e. totally Z-configurated.
The dimensions of the cavities for the $(2 d-h)$ joints consistently increase from 1.76 to $5.36 \AA$.

In the treatment of $Z-1 b$ dichloroethene by sodium selenide obtained from selenium, sodium hydroxide and reducing agent of rongalite (sodium hydroxymethylsulphinate), six unsaturated selenocrown esters (3a-f) were synthesised (total yield of $29 \%$ ) using 0.1 eq. of 15 -crown-5 ether additives [20] (Scheme 2). 
<smiles>Cl/C=C\Cl</smiles>

$n=0,3 \mathrm{a}(24 \%)^{*} ; n=3^{* *}, 3 \mathrm{~b}(6 \%) ; n=4,3 \mathrm{c}(22 \%) ;$ $n=5$, 3d (20\%); $n=6$, 3e (16\%); $n=7,3 f(12 \%)$.

* product concentration in the mixture, according to $\mathrm{H}$ NMR data.

** no traces of $n=1$ and 2 compounds were detected in the mixture.

As an example, the complexation of crown ether selenium with silver ions is presented in [20].

Type 2 unsaturated thiacrown ethers were also synthesised in the reaction of vinylidene chlo-

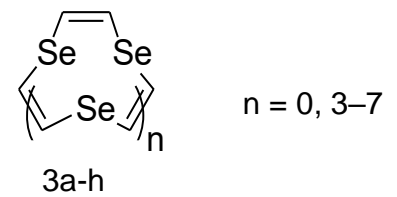

ride (1a) with sodium sulphide nonahydrate in acetonitrile with the presence of catalysts: 15-crown-5 or polyethylene glycol with a molecular weight of 300,750 and 2000 units [21]. In this case, an interesting feature of the reaction consists in the formation of 18-membered (4) and 21-membered (5) cycles with E-configuration of one of the double bonds in addition to the formation of (2a-h) cycles with exclusively Z-configuration of sulphur atoms in the double bond (Scheme 3).

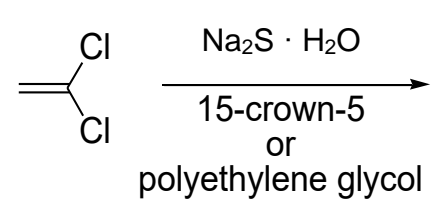

$1 \mathrm{a}$

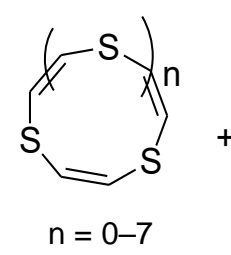

$2 a-h$<smiles>C1=C\S/C=C\S/C=C\S/C=C\S/C=C\S/1</smiles>

4
Scheme 3

Схема 3

$2 a-39 \% * ; 2 b-4 \% ; 2 c-$ no traces; $2 d-6 \%$; $2 \mathrm{e}-21 \% ; 2 f-13 \% ; 2 \mathrm{~g}-9 \% ; 2 \mathrm{~h}-5 \% ; 4-2 \%$; $5-2 \%$. Product concentration in the mixture, according to ${ }^{1} \mathrm{H}$ NMR data ( 0.4 equiv. of 15 -crown-5 catalyst, room temperature, duration of 48 hours). In the case of applying the polyethylene glycol (0.1-0.5 equiv.) as a catalyst, a mixture of thiacrown ethers of approximately the same composition was obtained with a maximum yield of $15 \%$.

According to the work [21], in the product mixture, the absence of compounds with a geminal arrangement of sulphur atoms relative to the double bond carbons is accounted for mechanism involving the isomerisation of the geminal intermediate into a vicinal product. The considered scheme of the mechanism illustrates the formation of E-configura-

ted cycles. However, according to the authors, the initial act of the process is presented by direct nucleophilic substitution of chlorine atoms in vinylidene chloride (1a), leading to contradiction in the inertness notion of halogen atoms attached to a double bond.

Using the "sulphur-hydrazine hydrate- $\mathrm{KOH}$ system generating exclusively $\mathrm{S}^{2-}$ anions at a $\mathrm{KOH}: S$ ratio exceeding 2 , the thiylation of (1a) and (1b) dichloroethenes easily proceeds at a temperature of $23^{\circ} \mathrm{C}$ and results in a mixture of three product types: 1,4-dithiin (2a) (16-31 and 14-46\% of yield, when using the (1a) and (1b) compounds, respectively), the (6) oligomer (26-75\%) and the (7) product of oxidative condensation of sulphur, i.e. a mixture of polysulphide anions $\mathrm{S}_{\mathrm{n}}{ }^{2-}\left(\mathrm{S}_{2}{ }^{2-}, \mathrm{S}_{3}{ }^{2-}\right.$ and even traces of $\mathrm{S}_{4}{ }^{2-}$ ) (Scheme 4) [22].<smiles>C=C(Cl)Cl</smiles>

$1 \mathrm{~b}$
$\mathrm{S} / \mathrm{N}_{2} \mathrm{H}_{4} \cdot \mathrm{H}_{2} \mathrm{O} / \mathrm{KOH}$

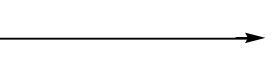<smiles>C1=CSC=CS1</smiles>
+ oligomer $+\mathrm{S}^{2-}$
6 


\section{I.B. Rozentsveig, V.S. Nikonova, N.A. Korchevin. Chalcogenisation of unsaturated...}

И.Б. Розенцвейг, В.С. Никонова, Н.А. Корчевин. Халькогенирование ненасыщенных...

In the case of applying (1a) dichloride and (1b) compound, the molecular weight of the resulting (6) oligomeric product comprises 2260-6120 and 1750-2000 units, respectively. Based on the elemental analysis data, the following structure was assigned to the oligomer:

$$
\begin{aligned}
& \mathrm{ClCH}=\mathrm{CH}-\mathrm{S}-(\mathrm{CH}=\mathrm{CH}-\mathrm{S}-)_{x^{-}} \\
& -(\mathrm{CH}=\mathrm{CHNHNH}-)_{y}-\mathrm{CH}=\mathrm{CHCl} .
\end{aligned}
$$

For oligomers obtained using the (1a) compound, the value of $x$ and $y$ was equal to $30-88$ and $6-15$, respectively. In the case of using the (1b) dichloride, the above values were 22-24 and $1-6$, respectively. According to IR spectroscopy and taking the results of the $E$ - and Z-polyvinyl sulphide (PVS) studies into account, the vinylene units in the oligomer chain are exclusively Z-configurated [23]. In current study, PVSs were obtained by polycondensation of $E$ - and $Z-1 \mathrm{~b}$ dichlorides with $E$ - and $Z$-isomers of hardly accessible sodium 1,2-ethendithiolate (Scheme 5).

The electrical conductivity of obtained PVS is also examined by the authors of work [23], and $E$, $E$-PVSs are demonstrated to possess higher conductivity in comparison with Z,Z-polymer with the $\lg \sigma$ value ranging approximately from $-4,5$ to $-6 \mathrm{~S} / \mathrm{cm}$ ).

Scheme 5

Схема 5
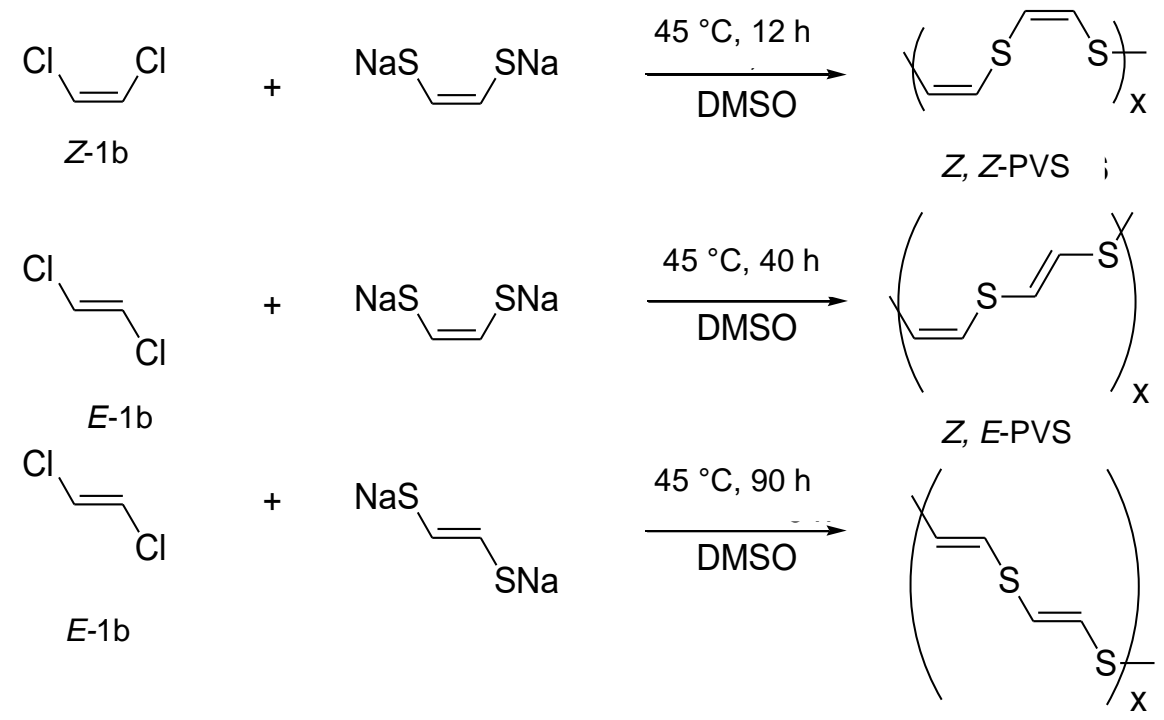

E, E-PVS

For 1,4-Ditiin (2a) in the reaction represented by Scheme 4 , the substantially higher yield is observed in comparison with the data, obtained by the authors of works [19, 21], and its separation from other reaction products proceeds quite easily. A slightly higher yield of $47 \%$ was established in the study for the reaction of $Z-1 b$ dichloride with $Z-1,2$-sodium ethanedithiolate in dry DMSO [24] (Scheme 6).

\section{Scheme 6 Схема 6}<smiles>Cl/C=C\Cl</smiles><smiles>[AsH2]/C=C\C=[AsH2]</smiles><smiles>C1CC1</smiles><smiles>C1=CSC=CS1</smiles>

$2 a$

After the separation of (2a) and (6) products, the formation of (7) polysulphide anions in the remaining aqueous hydrazine solution was confirmed by their alkylation by 1-bromopropane with the isolation and identification of dipropyl polysulphides.

The formation of the monotypic products presented in Scheme 4 under application of vinylidene chloride (1a) or both isomers of 1,2-dichloroethene (1b), as well as the participation of hydrazine in the formation of (6) oligomers, allowed the authors of [22] to propose a scheme for product formation having the primary key act consisting in the dehydrochlorination of (1) compounds with the formation of highly reactive chloroacetylene (8) (Scheme 7).

The (2a) compound involves an important ob ject for structural studies, making the development of preparatively available methods for its preparation to be an important synthetic task.

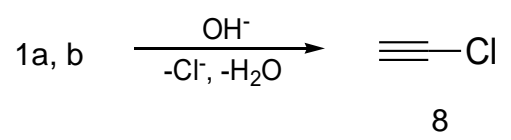


The presence of excess hydrazine in the reaction medium prevents the formation of macrocyclic structures presented in $[19,21]$ and, with the participation of (8) reagent and $\mathrm{S}^{2-}$ anions, results in the formation of nitrogen containing oligomers.

During the reaction of selenium and tellurium with (1a) vinylidene chloride under conditions similar to sulphur application, no analogues of 1,4-dithiine were isolated [25]. In the case of tellurium, the presence of diethyl telluride (9) is convincingly proved by the authors of this work with the formation accounted for the reductive hydrogenation of multiple bonds with the participation of hydrazine and telluride anions (Scheme 8).

\section{Scheme 8}

Схема 8

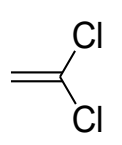

$1 \mathrm{a}$

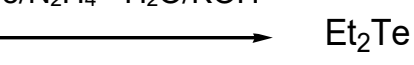

9
$\mathrm{Te} / \mathrm{N}_{2} \mathrm{H}_{4} \cdot \mathrm{H}_{2} \mathrm{O} / \mathrm{KOH}$

Tetrachloroethylene, a derivative of ethylene having four chlorine atoms, is the subject of largescale industrial production. Having relatively stable characteristics, this compound is widely applied in terms of a solvent for dry cleaning of textile materials and degreasing metal surfaces. The works $[26,27]$ describe only the interaction of tetrachlorethylene with sodium polysulphide $\mathrm{Na}_{2} \mathrm{~S}_{x}$ formed upon activation of sulphur with sodium sulphide $\mathrm{Na}_{2} \mathrm{~S} \cdot \mathrm{H}_{2} \mathrm{O}$ (Scheme 9) [27].

Scheme 9

Схема 9

$$
\mathrm{Na}_{2} \mathrm{~S} \cdot 9 \mathrm{H}_{2} \mathrm{O}+(\mathrm{x}-1) \mathrm{S} \longrightarrow \mathrm{Na}_{2} \mathrm{~S}_{\mathrm{x}}+9 \mathrm{H}_{2} \mathrm{O}
$$

In order to obtain an anhydrous polysulphide, water is removed by azeotropic distillation using octane.

The obtained anhydrous polysulphide $(x=2-5)$ reacts with tetrachlorethylene in a DMSO medium and a temperature of $90-110^{\circ} \mathrm{C}(1.5-3 \mathrm{~h})$ and forms polysulphide polymers having semiconductor properties (when doped with iodine, the electrical conductivity is $10^{-8} \mathrm{~S} / \mathrm{cm}$ ) [26]. According to the authors of this work, the obtained polymer is assumed to contain fully polycondensed structures (10-13), as well as fragments with incomplete polycondensation (14-16) (Scheme 10).

\section{Scheme 10} Схема 10<smiles>ClC(Cl)=C(Cl)Cl</smiles>
$+\mathrm{Na}_{2} \mathrm{~S}_{\mathrm{x}}$<smiles>C1CCCCC1</smiles>

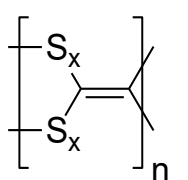

10

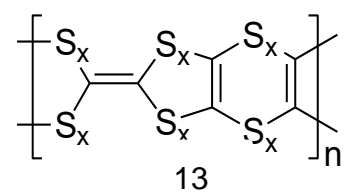
13<smiles>CSC(SC)=C(SC)SC</smiles>
14
The structure of fragments (10-15) was confirmed by reductive cleavage of polymers by the "hydrazine hydrate-alkali" system and subsequent methylation of cleavage products.

Although the reaction of tetrachlorethylene with $\mathrm{Na}_{2} \mathrm{~S}_{4}$ and $\mathrm{Na}_{2} \mathrm{~S}_{5}$ in aqueous alkaline DMF also results in polymer products, the $\mathrm{Na}_{2} \mathrm{~S}_{3}$ trisulphide in this reaction forms an individual compound of dimethylthioacetamide (17) with the participation of dimethylamine resulting from the alkaline hydrolysis of DMF [28] (Scheme 11).

The simplest chlorine derivative of propene, 3-chloropropene (allyl chloride), present a multi-ton product of industrial organochlorine synthesis. The high mobility of halogen in the allyl position ensures the production of a wide range of allyl chalcogenides [see, for example, 29, 30] studied in the chalcogen Claisen rearrangement of allylaryl (heteroaryl) chalcogenides [31, 32], identification the

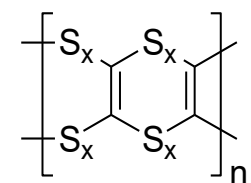

11<smiles></smiles>

12<smiles>CSC(SC)=C(SC)SC</smiles>

chalcogen atom characteristics affecting the allyl rearrangement in the series of allylphenylchalcogenides [33], as well as in the synthesis of various heterocyclic structures [34].

\section{Scheme 11}

Схема 11

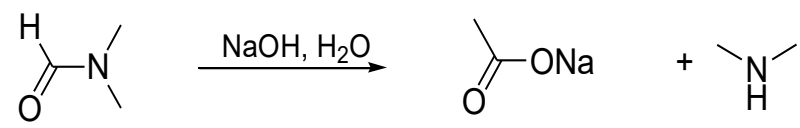

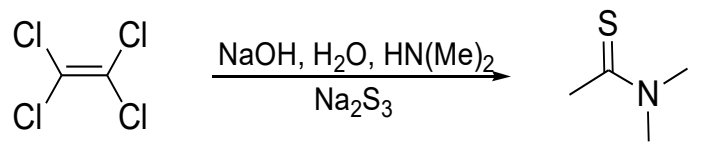


Halogen derivatives of propene and propyne

By application of AllX $(\mathrm{X}=\mathrm{Cl}, \mathrm{Br}, \mathrm{I})$ and elemental chalcogens in the hydrazine hydrate $/ \mathrm{KOH}$ system, all three diallyl chalcogenides were obtained [35]. As expected, allyl iodide is the most reactional, followed by bromide and chloride. When AllCl is introduced in the synthesis of diallyl selenide, the by-product of allyl propyl selenide is formed due to the participation of hydrazine and atmospheric oxygen, in other words, hydrogenation of one double bond is observed [35, 36]. In the presence of atmospheric oxygen in an alkaline medium, hydrazine forms a highly reactive diimide hydrogenating the intermediate-generated potassium allyl selenolate contained in the aqueous hydrazine phase (Scheme 12).

Scheme 12

Схема 12

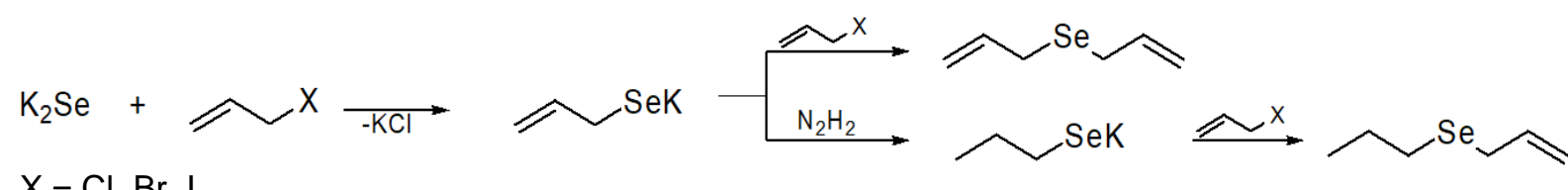

In parallel, the formed diallyl selenide and the allyl propyl selenide obtained by hydrogenation transits into the organic phase, avoiding further reduction. In the case of using allyl bromide, the reaction of diallyl selenide formation proceeds quickly and potassium allyl selenate transits from the aqueous hydrazine phase without hydrogenation [35].

The chalcogenisation of the dichloro-derivative of propene, 2,3-dichloropropene-1 (18a), was studied only in the hydrazine hydrate-base system. Dichloropropene (18a) with a $\mathrm{S}_{2}{ }^{2-}$ disulphide anion, generated in the hydrazine hydrate- $\mathrm{KOH}$ system at a ratio of $\mathrm{KOH}: \mathrm{S}=1: 1$ and yielded in $78 \%$, forms not an expected disulphide, but rather a monosulphide derivative (19) [ 37] (Scheme 13).

Scheme 13

Схема 13

Scheme 15

Схема 15

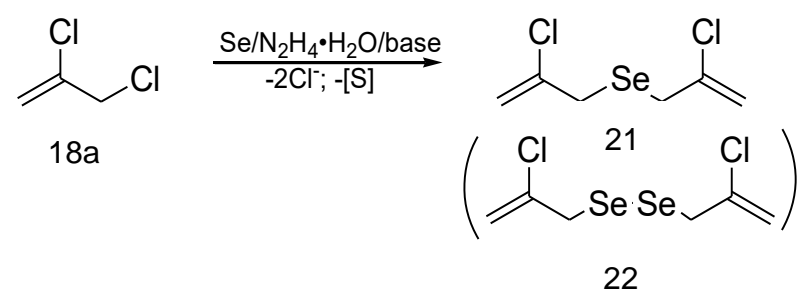

No tellurium-containing products are formed by tellurium in the $\mathrm{K}_{2} \mathrm{Te}$ or $\mathrm{K}_{2} \mathrm{Te}_{2}$ with dichloride forms (18a). The products of the reaction turned out to be propadiene (23) $(78 \%)$ and regenerated elemental tellurium [40] (Scheme 16).<smiles>C=C(Cl)CSCC(=C)Cl</smiles>

The corresponding disulphide (20) was obtainned in the yield of $70 \%$ by generating an anion disulphide in the hydrazine hydrate-monoethanolamine system [38] (Scheme 14).

Scheme 14

Схема 14

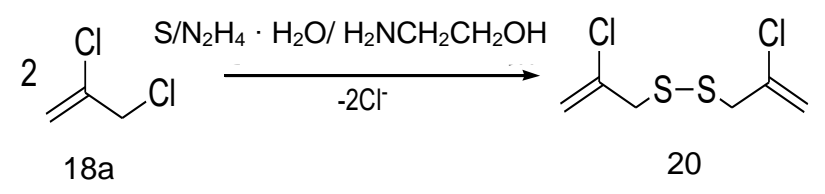

The diselenide anion obtained both in the hydrazine hydrate- $\mathrm{KOH}$ system and in the hydrazine hydrate-monoethanolamine system forms a monoselenide derivative (21) in a reaction with dichloride (18a) (72-70\% yield). However, in the latter case, diselenide (22) was identified with the yield of $7 \%$ [39] (Scheme 15).

Scheme 16

Схема 16<smiles>C=C(Cl)CCl</smiles>

$18 a$

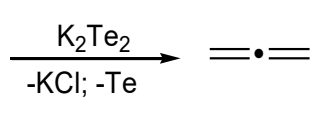

23

The proposed reaction can serve as a convenient preparative method for producing propadiene, which is widely used in various organic synthesis processes [41].

1,3-Dichloropropene (18b) presents an isomer of dichloride (18a) with the chlorine atoms located in the 1,3-positions. Commercial product (18b) consists of $E$ - and $Z$-isomers mixture with a proportion of $1.1: 1$. According to the work [42], in a reaction with (sulphur-hydrazine hydrate-base) systems, with either $\mathrm{KOH}$ or monoethanolamine is used as the base, dichloropropene (18b) behaves similarly to the 18a compound. In the first system, monosulphide (24) $(72 \%$ yield, a mixture of three geometric isomers) is formed during the generation of $\mathrm{S}_{2}{ }^{2-}$ anions (Scheme 17). When monoethanolamine is used as the base (also generating anions $\left.\mathrm{S}_{2}{ }^{2-}[13]\right)$, the corresponding disulphide (25) is quantitatively isolated. 


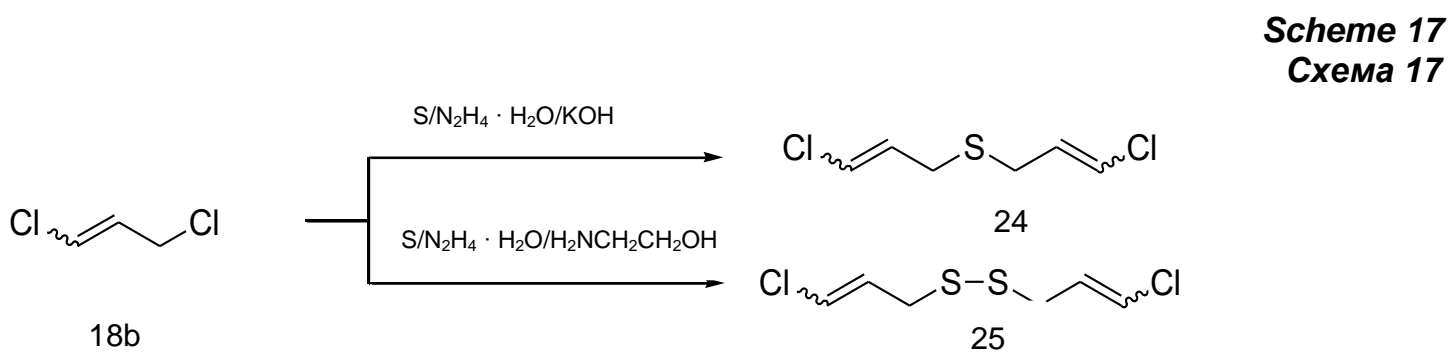

When applying selenium, a complex mixture of products is formed in both systems with the possibility of isolating the corresponding selenide in a yield of up to $15 \%$ [42].

The reaction of dichloropropene (18b) with tellurium in the hydrazine hydrate- $\mathrm{KOH}$ system appears to be completely different from the corresponding reaction of the isomer (18a) provided in Scheme 16. As a result of the interaction of dichloride (18b) with tellurium activated to $\mathrm{K}_{2} \mathrm{Te}$, diallyl telluride (26) was obtained with a yield of $57 \%$ (Scheme 18) [42]. This work discusses the mechanism of reductive cleavage of the $\mathrm{C}-\mathrm{Cl}$ bond with $s p^{2}$-hybridised carbon atom.

Scheme 18 Схема 18

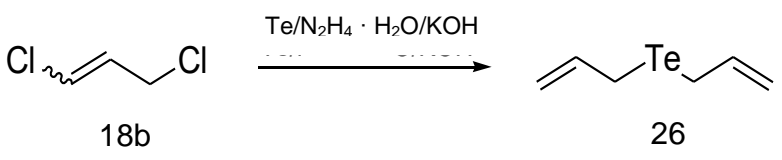

The method of obtaining diallyltelluride (26), presented in Scheme 18, turns to be preparatively more effective than the synthesis of this compound by allyl iodide.

Among the halogen derivatives of propyne, propargyl bromide (27) is most often applied in laboratory practice. By applying it under the action of sodium sulphide nanohydrate, dipropargyl sulphide (28) is obtained with a yield of $48 \%$ [43] (Scheme 19).

\section{Scheme 19} Схема 19

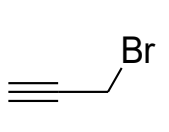

27

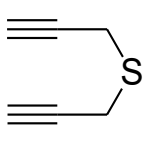

28

Dipropargyl selenide (29) is formed with a $61-70 \%$ yield in the reaction of two equivalents of propargyl bromide (27) with sodium selenide (Scheme 20), obtained during the reduction of selenium by $\mathrm{NaBH}_{4}$ in ethanol [44].

Scheme 20

Схема 20

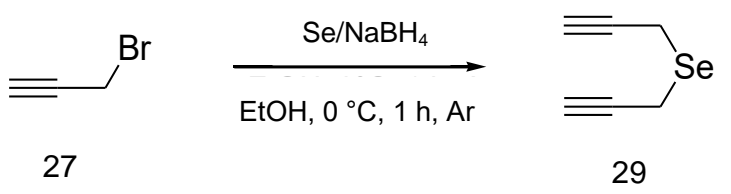

With the substitution of propargyl bromides, the corresponding substituted propargyl sulphide and selenide were obtained, some of which were successfully applied in the synthesis of heterocyclic compounds [45].

No dipropargyl telluride was obtained due to its extreme instability.

Chlorinated derivatives of butene

1,3-Dichlorobut-2-ene (30) was studied in the chalcogenisation reactions as a $\mathrm{C}_{4}$ unsaturated halogenated hydrocarbon. Dichloride (30) presents a waste product of chloroprene production. Using the (sulphur-hydrazine hydrate- $\mathrm{KOH}$ ) system (sulphur is activated to anions $\mathrm{S}_{2}{ }^{2-}$ ), the corresponding disulphide (31) was obtained from dichlorobutene (30) in $84 \%$ yield and successfully used in obtaining heterocyclic compounds: 5-methyl-1,2-dithiol-3-thione (32) and 3-thiophentiol (33) (Scheme 21) [46].

So far from this example, despite the fact that the dichloride (30) is a homolog of 1,3-dichloropropene (18b), its behaviour in chalcogenisation reactions appears to be significantly different.

\section{Scheme 21}

Схема 21

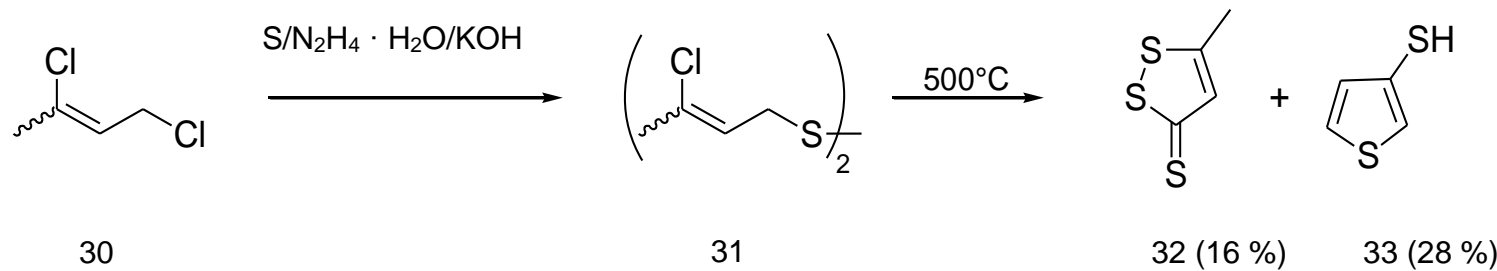

\section{CONCLUSION}

The presented research data demonstrate the possibility of obtaining valuable organochalcogen compounds using simple unsaturated halogen derivatives and elemental chalcogens with the simultaneous action of basic reduction systems. Due 
to the availability of precursors, the ease of implementation of the proposed methods and the high practical significance of the obtained products, the considered methods are a powerful tool in the development of organochalcogen synthesis and the expanded scope of OCC applications. For preparative purposes, the prospects and advanta- ges of using basic reduction systems based on hydrazine hydrate for chalcogen activation are presented in a particularly informative form. The authors hope the presented results will attract the attention of researchers involved in the synthesis, structural study and practical application of OCC.
1. Belen'kii LI. (ed.) Chemistry of organosulfur compounds: general problems. New York: Ellis Horwood; 1990.560 p.

2. McGarrigle EM, Myers EL, Illa O, Shaw MA, Riches SL, Aggarwal VK. Chalcogenides as organocatalysts. Chemical Reviews. 2007;107(12): 5841-5883. https://doi.org/10.1021/cr068402y

3. Nogami T, Tasaka Y, Inoe K, Mikawa $\mathrm{H}$. New conductive aliphatic tellurium polymers: poly(methylene ditelluride) and related polymers. Journal of the Chemical Society, Chemical Communications. 1985;5:269-271. https://doi.org/10.1039/C39 850000269

4. Petrovich YuA, Podorozhnaya RP. Selenoenzimes and other selenoproteins and their biological role. Uspekhi sovremennoi biologii. = Successes of modern biology. 1981;91(1):127-144. (In Russian)

5. Gusarova NK, Kuznetsova EE, Potapov VA Pushechkina TA, Fedoseev AP, Kirdei EG. Synthesis and biological activity of organylthioselenides. Khimiko-farmatsevticheskii zhurnal = Pharmaceutical Chemistry Journal. 1984;18(1):26-28. (In Russian)

6. Sadekov ID, Bargan IA, Maksimenko AA, Minkin VI. The study of tellurorganic compounds antibacterial properties. Khimiko-farmatsevticheskii zhurnal. = Pharmaceutical Chemistry Journal. 1982; 16(9):1073-1077. (In Russian)

7. Lin YA, Davis BG. The allylic chalcogen effect in the olefin metathesis. Belstein Journal of Organic Chemistry. 2010;6:1219-1228. https://doi.org/ 10.3762/bjoc.6.140

8. Trofimov BA, Shainyan BA. Vinyl sulfides. In: Patai S, Rappoport Z. (eds.) Chemistry of sulfurcontaining functional groups. Supplement $S$. New York: John Wiley \& Sons; 1993. P. 659-797.

9. Beletskaya IP, Ananikov VP. Unusual influence of the structures of transition metal complexes on catalytic C-S and C-Se bond formation under homogeneous and heterogeneous conditions. European Journal of Organic Chemistry. 2007;21: 3431-3444. https://doi.org/10.1002/ejoc.200700119

10. Shinada T, Fuji T, Ohtani $Y$, Yoshida $Y$, Ohfune $Y$. Syntheses of gabosine A, B, D, and $E$ from allyl sulfide derived from(-)-quinic acid. Synlett. 2002;8;1341-1343. https://doi.org/10.1055/s-200232985

11. Ma $S$, Hao X, Meng $X$, Huang $X$. Studies on the regio- and stereoselectivity of halohydroxylation of 1,2-allenyl sulfides or selenides. Journal of Organic Chemistry. 2004;69(17):5720-5724. https://doi. org/ 10.1021/jo049593c

12. Vasil'ev AA, Engman L. lodothyronine de- odinase mimics. Deiodination of $O, O^{\prime}$-diiodophenols by selenium and tellurium reagents. Journal of Organic Chemistry. 1998;63(12):3911-3917. https://doi. org/10.1021/jo972240b

13. Deryagina EN, Russavskaya NV, Papernaya LK, Levanova EP, Sukhomazova EN, Korchevin NA. Synthesis of organochalcogen compounds in basic reducing systems. Russian Chemical Bulletin. 2005;54(11):2473-2483. https://doi.org/10.1007/ s11172-006-0143-0

14. Levanova EP, Vakul'skaya TI, Shevchenko SG, Grabel'nykh VA, Sukhomazova EN, Elaev AV, et al. Synthesis and paramagnetic properties of polytelluride oligomers. Russian Journal of Organic Chemistry. 2008;44(10):1422-1427. https://doi.org/ 10.1134/S1070428008100047

15. Shainyan BA. Reactions involving bimolecular nucleophilic substitution at a vinyl centre. Russian Chemical Reviews. 1986;55(6):511-530. https://doi.org/10.1070/RC1986v055n06ABEH003205

16. Voronkov M.G., Deryagina E.N., Kuznetsova M.A., Kalikhman I.D. High-temperature organic synthesis. Reaction of vinyl chloride with hydrogen sulfide - new method for synthesis of vinyl thiol. Zhurnal organicheskoi khimii = Journal of Organic Chemistry. 1978;14(1):185-188. (In Russian)

17. Voronkov MG, Vlasova NN, Zhila GYu. Photochemical reaction of acetylene with hydrogen sulfide. Zhurnal organicheskoi khimii = Journal of Organic Chemistry 1984;20(1):211-212. (In Russian)

18. Lown EM, Dedio EL, Strausz OP, Gunning NE. The reactions of sulfur atoms. VIII. Further investigation of the reactions with olefins. Relative rates of addition of sulfur $\left({ }^{3} \mathrm{P}\right)$ and $\left({ }^{1} \mathrm{D}\right)$ atoms. Journal of the American Chemical Society. 1967;89(5): 1056-1062. https://doi.org/10.1021/ja00981a003

19. Tsuchiya T, Shimizu T, Kamigata N. Unsaturated thiacrown ethers: synthesis, physical properties, and formation of a silver complex. Journal of the American Chemical Society. 2001;123(47): 11534-11538. https://doi.org/10.1021/ja0102742

20. Shimizu T, Kawaguchi M, Tsuchiya T, Hirabayashi K, Kamigata N. Unsaturated selenacrown ethers: synthesis, structure, and formation of silver complexes. Journal of Organic Chemistry. 2005;70(13): 5036-5044. https://doi.org/10.1021/jo0502807

21. Sun $D-Q$, Yang J-K. An economical approach to the synthesis of unsaturated thiacrown ethers. Synthesis. 2011;15:2454-2458. https://doi.org/ 10.1055/s-0030-1260066

22. Levanova EP, Nikonova VS, Grabel'nykh VA, Russavskaya NV, Albanov Al, Rozentsveig IB, et al. 
Reactions of Dichloroethenes with Sulfur in the System Hydrazine hydrate-KOH. Russian Journal of General Chemistry. 2018;88(3):383-388. https://doi.org/ 10.1134/S1070363218030015

23. Ikeda Y, Nagoya I, Ozaki M. Electronic states and electrical conductivities of polyvinylenesulphides. Synthetic Metals. 1987;21(2):235-240. https://doi.org/10.1016/0379-6779(87)90092-0

24. Russell J. The NMR spectra of 1,4-dioxin and 1,4-dithiin partially oriented in a nematic phase. Organic Magnetic Resonance. 1972;4(3):433-439. https://doi.org/10.1002/mrc.1270040310

25. Levanova EP, Nikonova VS, Grabel'nykh VA, Russavskaya NV, Albanov AI, Rozentsveig IB, et al. Reactions of 1,1-Dichloroethene with elemental chalcogens in the system hydrazine hydrate-alkali. Russian Journal of Organic Chemistry. 2016;52(7): 1070-1071. https://doi.org/10.1134/S1070428016070307

26. Trofimov BA, D'yachkova SG, Gusarova NK, Sinegovskaya LM, Myachina GF, Korzhova SA, et al. The synthesis of polysulfide polymers from tetrachloroethene and sodium polysulfides. Sulfur Letters. 1999;22(5):169-177.

27. Sultangareev PG, Rozinov VG, Albanov AV, Voronkov MG. Reactions of Polychloroethylenes with Sodium Polysulfides in Aqueous-Alkaline Dimethylformamide. Russian Journal of General Chemistry. 2003;73(2):325-236. https://doi.org/10. 1023/A:1024781130432

28. Trofimov BA, D'yachcova SG, Scotheim $T$, Gusarova NK, Myachina GF, Korzhova SA, et al. Reduction of poly[dicarbon polysulfides] synthesized from tetrachloroethene and sodium polysulfides. Sulfur Letters. 1999;23(1):33-47. https://doi.org/10.10 80/10426500008045219

29. Deryagina EN, Korchevin NA, Papernaya LK. Новые пути синтеза несимметричных диорганилсульфидов New ways for the synthesis of asymmetric diorganyl sulfides. Zhurnal obshchei khimii = Journal of General Chemistry. 1997;67(5): 866-869. (In Russian)

30. Kataev EG, Kataeva LM, Chmutova GA. Allyl phenyl selenide and its prototropic isomerization. Zhurnal organicheskoy khimii = Journal of Organic Chemistry. 1966;2(12):2244-2248. (In Russian)

31. Kwart $H$, Evans R. The thio-Claisen rearrangement. The mechanism of thermal rearrangement of allyl aryl sulphides. Journal of Organic Chemistry. 1966;31(2):413-419. https://doi.org/10. 1021/jo01340a016

32. Mortensen JZ, Hedegaard B, Lawesson S-O. Thiophene chemistry. XVII. Thio-Claisen rearrangement of allyl thienyl sulfides. Tetrahedron. 1971; 27(10):3831-3838. https://doi.org/10.1016/S00404020(01)98244-4

33. Anisimov AV, Viktorova EA, Danilova TA. Molecular rearrangements of organosulfur compounds. Moscow: Moscow State University; 1989, 122 p. (In Russian).

34. Korchevin NA, Sukhomazova ÉN, Russavskaya NV, Turchaninova LP, Sigalov MV, Klyba LV, et al. Thermal transformations of allyl 2-thienyl sulfide and selenide. Chemistry of Heterocyclic Compounds. 1991;27(10):1049-1052. https://doi.org/10. 1007/BF00486794

35. Deryagina EN, Korchevin NA, Russavskaya NV, Grabel'nykh VA. A mechanism of the hydrogenation of the double bond in the synthesis of allyl chalcogenides in the hydrazine hydratepotassium hydroxide system. Russian Chemical Bulletin. 1998;47(9):1827-1829. https://doi.org/10. 1007/BF02495714

36. Amosova SV, Musorin GK, Kopylova IG, Keiko VV. Allyl propyl selenide formation in reaction of $\mathrm{Se}-\mathrm{KOH}-\mathrm{N}_{2} \mathrm{H}_{4} \cdot \mathrm{H}_{2} \mathrm{O}$ with allyl chloride. Zhurnal obshchey khimii = Journal of General Chemistry. 1990;60(2):473. (In Russian)

37. Levanova EP, Grabel'nykh VA, Russavskaya NV, Klyba LV, Zhanchipova ER, Albanov Al, et al. Reactions of 2,3-dichloro-1-propene with sulfur and tellurium in the system hydrazine hydrate$\mathrm{KOH}$. Russian Journal of General Chemistry. 2009;79(6):1097-1101 https://doi.org/10.1134/S107 0363209060103

38. Levanova EP, Grabel'nykh VA, Russavskaya NV, Rozentsveig IP, Tarasova OA, Korchevin NA. Reaction of 2,3-dichloroprop-1-ene with sulfur in hydrazine hydrate-monoethanolamine system. Russian Journal of General Chemistry. 2011; 81(3):611-612. https://doi.org/10.1134/S107036321 1030315

39. Levanova EP, Grabel'nykh VA, Russavskaya NV, Albanov Al, Elaev AV, Tarasova OA, et al. Features of the reaction of 2,3-dichloroprop-1-ene with selenium in a hydrazine hydrate - base systems. Russian Journal of General Chemistry. 2011; 81(7):1560-1561.

40. Levanova EP, Vshivtsev VYu, Grabel'nykh VA, Sukhomazova EN, Russavskaya NV, Albanov Al, et al. Reaction of tellurium with 2,3-dichloro-1-propene in the system hydrazine hydratealkali. A novel approach to synthesis of allene. Russian Journal of General Chemistry. 2008;78(10): 1980-1981. https://doi.org/10.1134/S1070363208100289

41. Taber AM, Mushina EA, Krentsel' BA. Allen hydrocarbons: production, properties, application. Moscow: Nauka; 1987. 205 p. (In Russian)

42. Levanova EP, Nikonova VS, Grabel'nykh VA, Rozentsveig IB, Russavskaya NV, Albanov Al, et al. Chalcogenation of 1,3-dichloropropene with elemental chalcogens in the system hydrazine hydrate base. Russian Journal of General Chemistry. 2016; 86(6):1282-1287. https://doi.org/10.1134/S1070363 216060104

43. Gal Y-S, Choi S-K. Cyclopolymerization of dipropargyl sulfide by transition metal catalysts. Journal of Polymer Science. Part C: Polymer Letters. 1988;26(2):115-121. https://doi.org/10.1002/ pol.1988.140260210

44. Amosova SV, Martynov AV. Dipropargyl selenide. Russian Journal of Organic Chemistry. 2011; 47(11):1282-1287. https://doi.org/10.1134/ 
45. Braverman S, Zafrani Y, Gottlieb HE. Base catalyzed rearrangement of $\pi$-conjugated sulfur and selenium bridged propargylic systems. Tetrahedron. 2001;57(44):9177-9185. https://doi.org/10.1016/S0 040-4020(01)00923-1

46. Turchaninova LP, Sukhomazova EN, Leva- nova EP, Korchevin NA, Deryagina EN, Voronkov MG. High-temperature organic synthesis XL. Thermal heterocyclization of bis(3-chloro-2-butenyl)disulfide. Zhurnal organicheskoy khimii $=$ Journal of Organic Chemistry. 1992;28(12):2473-2476. (In Russian)

\section{БИБЛИОГРАФИЧЕСКИЙ СПИСОК}

1. Получение и свойства органических соединений серы / под ред. Л.И. Беленького. М.: Химия. 1998. 560 с.

2. McGarrigleE.M., Myers E.L, llla O., Shaw M.A., Riches S.L., Aggarwal V.K. Chalcogenides as organocatalysts // Chemical Reviews. 2007. Vol. 107. Issue 12. P. 5841-5883. https://doi.org/10.1021/cr 068402y

3. Nogami T., Tasaka Y., Inoe K., Mikawa H. New conductive aliphatic tellurium polymers: poly(methylene ditelluride) and related polymers // Journal of the Chemical Society, Chemical Communications. 1985. Issue 5. P. 269-271. https://doi.org/10. 1039/C39850000269

4. Петрович Ю.А., Подорожная Р.П. Селеноэнзимы и другие селенопротеины. Их биологическое значение // Успехи современной биологии. 1981. Т. 91. N 1. С. 127-144.

5. ГусароваН.К., КузнецоваЭ.Э., Потапов В.А., Пушечкина Т.А., Федосеев А.П., Кирдей Е.Г. [и др.]. Синтез и биологическая активность органилтиоселенидов // Химико-фрармацевтический журнал. 1984. Т. 18. N 1. С. 26-28.

6. Садеков ИД., Барган И.А., Максименко А.А., МинкинВ.И. Изучение антибактериальных свойств теллуроорганических соединений // Химикофармацевтический журнал. 1982. Т. 16. N 9. C. 1073-1077.

7. Lin Y.A., Davis B.G. The allylic chalcogen effect in the olefin metathesis // Belstein Journal of Organic Chemistry. 2010. No. 6. P. 1219-1228. https://doi.org/10.3762/bjoc.6.140

8. Trofimov B.A., Shainyan B.A. Vinyl sulfides. Edited by Patai S., Rappoport Z. Chemistry of sulfur-containing functional groups. Supplement $S$. New York: John Wiley \& Sons. 1993. P. 659-797.

9. Beletskaya I.P., Ananikov V.P. Unusual influence of the structures of transition metal complexes on catalytic C-S and C-Se bond formation under homogeneous and heterogeneous conditions // European Journal of Organic Chemistry. 2007. Issue 21. P. 3431-3444. https://doi.org/10.1002/ ejoc. 200700119

10. Shinada T., Fuji T., Ohtani Y., Yoshida Y., Ohfune Y. Syntheses of gabosine A, B, D, and E from allyl sulfide derived from(-)-quinic acid // Synlett. 2002. Issue 8. P. 1341-1343. https://doi.org/10. 1055/s-2002-32985

11. Ma S., Hao X., Meng X., Huang X. Studies on the regio- and stereoselectivity of halohydroxylation of 1,2-allenyl sulfides or selenides // Journal of Organic Chemistry. 2004. Vol.69. Issue 17. P. 5720-5724. https://doi.org/10.1021/j0049593c
12. Vasil'ev A.A., Engman L. lodothyronine deiodinase mimics. Deiodination of $O, O^{\prime}$-diiodophenols by selenium and tellurium reagents // Journal of Organic Chemistry. 1998. Vol. 63. Issue 12. P. 39113917. https://doi.org/10.1021/jo972240b

13. Deryagina E.N., Russavskaya N.V., Papernaya L.K., Levanova E.P., Sukhomazova E.N. Korchevin N.A. Synthesis of organochalcogen compounds in basic reducing systems // Russian Chemical Bulletin. 2005. Vol. 54. Issue 11, P. 2473-2483. https://doi.org/10.1007/s11172-006-0143-0

14. Levanova E.P., Vakul'skaya T.I., Shevchenko S.G., Grabel'nykh V.A., Sukhomazova E.N., Elaev A.V., et al. Synthesis and paramagnetic properties of polytelluride oligomers // Russian Journal of Organic Chemistry. 2008. Vol. 44. Issue 10, P. 1422-1427. https://doi.org/10.1134/S107042800 8100047

15. Shainyan B.A. Reactions involving bimolecular nucleophilic substitution at a vinyl centre // Russian Chemical Reviews. 1986. Vol. 55. Issue 6. P. 511-530. https://doi.org/10.1070/RC1986v055n0 6ABEH003205

16. Воронков М.Г., Дерягина Э.Н., Кузнецова М.А., Калихман И.Д. Высокотемпературный органический синтез. Реакция хлористого винила с сероводородом - новый метод синтеза винилтиола // Журнал органической химии. 1978. T. 14. N 1. C. $185-188$.

17. Воронков М.Г., Власова Н.Н., Жила Г.Ю. Фотохимическая реакция ацетилена с сероводородом // Журнал органической химии. 1984. T. 20. N 1. C. 211-212.

18. Lown E.M., Dedio E.L., Strausz O.P., Gunning N.E. The reactions of sulfur atoms. VIII. Further investigation of the reactions with olefins. Relative rates of addition of sulfur $\left({ }^{3} \mathrm{P}\right)$ and $\left({ }^{1} \mathrm{D}\right)$ atoms // Journal of the American Chemical Society. 1967. Vol. 89. No. 5. P. 1056-1062. https://doi.org/10. 1021/ja00981a003

19. Tsuchiya T., Shimizu T., Kamigata N. Unsaturated thiacrown ethers: synthesis, physical properties, and formation of a silver complex // Journal of the American Chemical Society. 2001. Vol. 123. Issue 47. P. 11534-11538. https://doi.org/ 10.1021/ja0102742

20. Shimizu T., Kawaguchi M., Tsuchiya T., Hirabayashi K., Kamigata N. Unsaturated selenacrown ethers: synthesis, structure, and formation of silver complexes // Journal of Organic Chemistry. 2005. Vol. 70. Issue 13. P. 5036-5044. https://doi. org/10.1021/jo0502807

21. Sun D.-Q., Yang J.-K. An economical ap- 
proach to the synthesis of unsaturated thiacrown ethers // Synthesis. 2011. No. 15. P. 2454-2458. https://doi.org/10.1055/s-0030-1260066

22. Levanova E.P., Nikonova V.S., Grabel'nykh V.A., Russavskaya N.V., Albanov A.I., Rozentsveig I.B., et al. Reactions of Dichloroethenes with Sulfur in the System Hydrazine Hydrate $-\mathrm{KOH}$ // Russian Journal of General Chemistry. 2018. Vol. 88. Issue 3. P. 383-388. https://doi.org/10.11 34/ S1070363218030015

23. Ikeda Y., Nagoya I., Ozaki M. Electronic states and electrical conductivities of polyvinylenesulphides // Synthetic Metals. 1987. Vol. 21. No. 2. P. 235-240. https://doi.org/10.1016/0379-6779(87) 90092-0

24. Russell J. The NMR spectra of 1,4-dioxin and 1,4-dithiin partially oriented in a nematic phase // Organic Magnetic Resonance. 1972. Vol. 4. No. 3. P. 433-439. https://doi.org/10.1002/mrc.12 70040310

25. Levanova E.P., Nikonova V.S., Grabel'nykh V.A., Russavskaya N.V., Albanov A.I., Rozentsveig I.B., et al. Reactions of 1,1-Dichloroethene with elemental chalcogens in the system hydrazine hydrate-alkali // Russian Journal of Organic Chemistry. 2016. Vol. 52. Issue 7, P. 1070-1071. https://doi.org/ 10.1134/S1070428016070307

26. Trofimov B.A., D'yachkova S.G., Gusarova N.K., Sinegovskaya L.M., Myachina G.F., Korzhova S.A., et al. The synthesis of polysulfide polymers from tetrachloroethene and sodium polysulfides // Sulfur Letters. 1999. Vol. 22. Issue 5. P. 169-177.

27. Sultangareev P.G., Rozinov V.G., Albanov A.V., Voronkov M.G. Reactions of Polychloroethylenes with Sodium Polysulfides in AqueousAlkaline Dimethylformamide // Russian Journal of General Chemistry. 2003. Vol. 73. Issue 2. P. 325-236. https://doi.org/10.1023/A:1024781130432

28. Trofimov B.A., D'yachcova S.G., Scotheim T., Gusarova N.K., Myachina G.F., Korzhova S.A., et al. Reduction of poly[dicarbon polysulfides] synthesized from tetrachloroethene and sodium polysulfides // Sulfur Letters. 1999. Vol. 23. No. 1. P. 33-47. https://doi.org/10.1080/10426500008045219

29. Дерягина Э.Н., Корчевин Н.А., Папер ная Л.К. Новые пути синтеза несимметричных диорганилсульфидов // Журнал общей химии. 1997. T. 67. N 5. C. 866-869.

30. Катаев Е.Г., Катаева Л.М., Чмутова Г.А. Аллилфенилселенид и его прототропная изомеризация // Журнал органической химии. 1966. T. 2. N 12. C. 2244-2248.

31. Kwart H., Evans R. The thio-Claisen rearrangement. The mechanism of thermal rearrangement of allyl aryl sulphides // Journal of Organic Chemistry. 1966. Vol. 31. No. 2. P. 413-419. https://doi.org/10.1021/jo01340a016

32. Mortensen J.Z., Hedegaard B., Lawesson S.-O. Thiophene chemistry. XVII. Thio-Claisen rearrangement of allyl thienyl sulfides // Tetrahedron.
1971. Vol.27. No. 10. P. 3831-3838. https://doi.org/ 10.1016/S0040-4020(01)98244-4

33. Анисимов А.В., Викторова Е.А., Данилова Т.А. Молекулярные перегруппировки сероорганических соединений. Органические сульфиды. М.: Изд-во МГУ. 1989. 122 с.

34. Korchevin N.A., Sukhomazova É.N., Russavskaya N.V., Turchaninova L.P., Sigalov M.V., Klyba L.V., et al. Thermal transformations of allyl 2-thienyl sulfide and selenide // Chemistry of Heterocyclic Compounds. 1991. Vol. 27. Issue 10. P. 1049-1052. https://doi.org/10.1007/BF00486794

35. Deryagina E.N., Korchevin N.A., Russavskaya N.V., Grabel'nykh V.A. A mechanism of the hydrogenation of the double bond in the synthesis of allyl chalcogenides in the hydrazine hydratepotassium hydroxide system // Russian Chemical Bulletin. 1998. Vol. 47. Issue 9. P. 1827-1829. https://doi.org/10.1007/BF02495714

36. Амосова С.В., Мусорин Г.К., Копылова И.Г., Кейко В.В. Образование аллилпропилселенида при взаимодействии системы $\mathrm{Se}-\mathrm{KOH}-\mathrm{N}_{2} \mathrm{H}_{4} \cdot \mathrm{H}_{2} \mathrm{O}$ с хлористым аллилом // Журнал общей химии. 1990. T. 60. N 2. C. 473.

37. Levanova E.P., Grabel'nykh V.A., Russavskaya N.V., Klyba L.V., Zhanchipova E.R., Albanov A.I., et al. Reactions of 2,3-dichloro-1-propene with sulfur and tellurium in the system hydrazine hydrate-KOH // Russian Journal of General Chemistry. 2009. Vol. 79. Issue 6. P. 1097-1101 https://doi.org/ 10.1134/S1070363209060103

38. Levanova E.P., Grabel'nykh V.A., Russavskaya N.V., Rozentsveig I.P., Tarasova O.A., Korchevin N.A. Reaction of 2,3-dichloroprop-1-ene with sulfur in hydrazine hydrate-monoethanolamine system // Russian Journal of General Chemistry. 2011. Vol. 81. Issue 3. P. 611-612. https://doi.org/10.113 4/S1070363211030315

39. Levanova E.P., Grabel'nykh V.A., Russavskaya N.V., Albanov A.I., Elaev A.V., Tarasova O.A., et al. Features of the reaction of 2,3-dichloroprop1-ene with selenium in a hydrazine hydrate - base systems // Russian Journal of General Chemistry. 2011. Vol. 81. Issue 7. P. 1560-1561.

40. Levanova E.P., Vshivtsev V.Yu., Grabel'nykh V.A., Sukhomazova E.N., Russavskaya N.V., Albanov A.l., et al. Reaction of tellurium with 2,3-dichloro-1-propene in the system hydrazine hydrate-alkali. A novel approach to synthesis of allene // Russian Journal of General Chemistry. 2008. Vol. 78. Issue 10. P. 1980-1981 https://doi.org/ 10. $1134 / \mathrm{S} 1070363208100289$

41. Табер А.М., Мушина Е.А., Кренцель Б.А. Алленовые углеводороды: получение, свойства, применение. М.: Наука. 1987. 205 с.

42. Levanova E.P., Nikonova V.S., Grabel'nykh V.A., Rozentsveig I.B., Russavskaya N.V., Albanov A.l., et al. Chalcogenation of 1,3-dichloropropene with elemental chalcogens in the system hydrazine hydrate - base // Russian Journal of General Chemistry. 2016. Vol. 86. Issue 6 P. 1282-1287. 
https://doi.org/10.1134/S1070363216060104

43. Gal Y.-S., Choi S.-K. Cyclopolymerization of dipropargyl sulfide by transition metal catalysts // Journal of Polymer Science. Part C: Polymer Letters. 1988. Vol. 26. No. 2. P. 115-121. https://doi.org/ 10.1002/pol.1988.140260210

44. Amosova S.V., Martynov A.V. Dipropargyl selenide // Russian Journal of Organic Chemistry. 2011. Vol. 47. Issue 11. P. 1282-1287. https://doi.org/ 10.1134/

45. Braverman S., Zafrani Y., Gottlieb H.E. Base

\section{Contribution}

Igor B. Rozentsveig, Valentina S. Nikonova, Nikolai A. Korchevin analyzed the data, summarized the material and wrote the manuscript. Igor B. Rozentsveig, Valentina S. Nikonova, Nikolai A. Korchevin have equal author's rights and bear equal responsibility for plagiarism.

\section{Conflict of interests}

The authors declare no conflict of interests regarding the publication of this article.

The final manuscript has been read and approved by all the co-authors.

\section{AUTHORS' INDEX}

Igor B. Rozentsveig,

Dr. Sci. (Chemistry), Associated Professor, Head of Laboratory of Haloorganic Compounds,

A.E. Favorsky Irkutsk Institute

of Chemistry SB RAS,

1, Favorsky St., Irkutsk, 664033,

Russian Federation;

Professor,

Department of Theoretical

and Applied Organic Chemistry

and Polymerization Processes,

Irkutsk State University,

1, K. Marks St., Irkutsk, 664003,

Russian Federation,

凹e-mail: i_roz@irioch.irk.ru

Valentina S. Nikonova,

Cand. Sci. (Chemistry), Reseacher,

A.E. Favorsky Irkutsk Institute

of Chemistry SB RAS,

1, Favorsky St., Irkutsk, 664033,

Russian Federation;

e-mail: valentina_serg@inbox.ru catalyzed rearrangement of $\pi$-conjugated sulfur and selenium bridged propargylic systems // Tetrahedron. 2001. Vol. 57. Issue 44. P. 9177-9185. https://doi.org/10.1016/S0040-4020(01)00923-1

46. Турчанинова Л.П., Сухомазова Э.Н., Леванова Е.П., Корчевин Н.А., Дерягина Э.Н., Воронков М.Г. Высокотемпературный органический синтез XL. Термическая гетероциклизация бис(3-хлор-2-бутенил)дисульфида // Журнал органической химии. 1992. Т. 28. N 12. С. 2473-2476.

\section{Kритерии авторства}

Розенцвейг И.Б., Никонова В.С., Корчевин Н.А. проанализировали литературные источники, обобщили имеющийся по данной теме материал и написали рукопись. Розенцвейг И.Б., Никонова В.С., Корчевин Н.А. имеют на статью равные авторские права и несут равную ответственность за плагиат.

\section{Конфоликт интересов}

Авторы заявляют об отсутствии конфрликта интересов.

Все авторы прочитали и одобрили окончательный вариант рукописи.

\section{СВЕДЕНИЯ ОБ АВТОРАХ}

\section{Розенцвейг Игорь Борисович,}

д.Х.н., доцент, заведующий лабораторией галогенорганических соединений, Иркутский институт химии им. А.Е. Фаворского СО РАН, 664033, г. Иркутск, ул. Фаворского, 1 , Российская Федерация; професссор кафедры теоретической и прикладной органической химии и полимеризационных процессов, Иркутский государственный университет, 664003, ул. К. Маркса, 1,

Российская Федерация, \e-mail: i_roz@irioch.irk.ru

\author{
Никонова Валентина Сергеевна, \\ к.Х.Н., научный сотрудник, \\ Иркутский институт химии \\ им. А.Е. Фаворского СО РАН, \\ 664033, г. Иркутск, ул. Фаворского, 1 , \\ Российская Федерация, \\ e-mail: valentina_serg@inbox.ru
}


Nikolai A. Korchevin,

Dr. Sci. (Chemistry), Professor, Leading Researcher,

A.E. Favorsky Irkutsk Institute of Chemistry SB RAS,

1, Favorsky St., Irkutsk 664033,

Russian Federation;

Professor,

Department of Electrochemical

Production Technologies,

Angarsk State Technical University,

60, Chaikovsky St., Angarsk 665835,

Russian Federation,

e-mail: rusnatali64@yandex.ru
Корчевин Николай Алексеевич,

д.X.Н., профессор,

ведущий научный сотрудник,

Иркутский институт химии

им. А.Е. Фаворского СО РАН,

664033 , г. Иркутск, ул. Фаворского, 1 ,

Российская Федерация;

профессор кафедры технологии

электрохимических производств,

Ангарский государственный

технический университет,

665835 , г. Ангарск, ул. Чайковского, 60,

Российская Федерация,

e-mail: rusnatali64@yandex.ru 